\title{
FROM BIOETHICS - TO NOOETHICS
}

\author{
Zaporozhan V. N. \\ Odessa State Medical University, Ukraine
}

Reviewed by: Prof. A. Klissarova, MD, PhD, D.Sci

\begin{abstract}
Bioethics formation should be considered as a logic prolongation of medical ethics history. There are some signs of bioethics transition into qualitatively other level of existence as a science. Thus, it is expedient to differentiate biomedical ethics as a stage of development of medical ethics and bioethics as more extended field of knowledge that makes its task to protect physical, mental and spiritual integrity of man, its genome, protect animal and plant world and environment. In the 20-th century the mankind faced the disastrous consequences of global ecological crisis. This principally new phenomenon raised a question of physical survival, continuation of the human race and development of civilization. From our point of view, it is appropriate to include the notion of "global bioethics" into terminological use (i.e. bioethics in the broad sense). Biomedical ethics and ecoethics should be considered as its constituents. Undoubtedly, modern society is in Noospheric crisis, it's destructive consequences are enormous and the outcome is unpredictable. The Noospheric crisis consists in increased chaos, simplification of the system "mankind-nature", and may be characterized as a direct consequence of the thermodynamic law of growing entropy. If the human activity in the Noosphere does not begin to be regulated with new ethic principles, the consequences of modern noospherical crisis may have global and disastrous character. For the maintenance of all living, for all nature and ecosystem on the whole, this new ethics has to become Nooethics, i.e. to become the rules of behavior in the Noosphere, which would promote the global interests of all Noosphere components such as: the Planet, mankind and Biosphere, transformed by it.
\end{abstract}

Keywords: bioethics, nooethics, history.

Interest to the philosophic and ideological problems of bioethics in our country, which has declared adherence to the principles of democratic renovation of society, humanism and advocacy of human rights is great and evident. The way of moral personality formation has been developing for centuries but it is still far from the completion. The sources of medical ethics are associated with the formation of general mankind ethics and organisation of professional edicine.

Analysis of philosophic and ideological fundamentals of the modern stage of bioethics development assumes the discussion of the following problems:

1). Are there differences between the terms "biomedical ethics" and "bioethics"? If the answer is positive, then are they essential and what do they exactly consist of?

2). What is historical relations of medical ethics to biomedical ethics and global bioethics?

3 ). What is the essence of the modern stage of global bioethics development and may it be characterized by the introduction of a new term "nooethics"?

4). Is it possible to create the universal integration theory of global bioethics and nooethics?

5). Is it necessary to teach bioethics in higher medical educational institutions?
Bioethics formation should be considered as a logic prolongation of medical ethics history. On the other hand, bioethics itself isn't the final stage of development of ethic thought applied to medico-and-biological theory and practice. Moreover, there are some signs of bioethics transition into qualitatively other level of existence as a science. Reaching this level requires terminological assessments on the basis of historical precondition analysis, ideological fundamentals and philosophic aspects of medical ethics and bioethics development.

We consider the discussion on the problem whether it's possible and expedient to use the terms "biomedical ethics" and "bioethics" as synonyms or these terms are interchangeable to be significant. It occurs frequently and everywhere in real life. If one regards these terms to be synonyms, then "bioethics" and "biomedical ethics" will have double meaning and the semantic load will be uncertain and not in the full form. On the one hand, bioethics (and biomedical ethics) should be considered as words having the same meaning of the stage of the professional medical ethics development. On the other hand, according to V.Potter's idea (1970) who was the founder of the given subject, bioethics is "a bridge", "a connecting link" for the integral combination of biology and ethics, which are essentially different phenomena. According to V. Potter, bioethics is 
not only a bridge between different subjects but it is "a bridge to the future", which is necessary for the connecting "medical ethics and environmental ethics on the worldwide scale to ensure man's survival". Thus, there is a double meaning in the definition of bioethics which should be overcome by more exact use of terminology.

From our viewpoint it is expedient to regard the terms "biomedical ethics" and "bioethics" to be synonyms. It is appropriate to use the term "biomedical ethics" while analysing the ethic problems being associated with practical medicine. In this case practical medicine should be meant in the wide sense and must include the professional activity of not only the doctors but also the activity of other specialists of public health. On the one hand, biomedical (or clinical ethics in the above-mentioned meaning is regarded as the next stage of medical ethics development and foundation for forming scientifically based balance between the newest medico-and-biological engeneering and the human rights, principles of humanism, social progress - on the other hand. In such a case, bioethics may be defined in the primary meaning of "a bridge to the future", life ethics, which deals with ethics problems not only of man but also of all living organisms as well as the problems of preserving the environment. Initially the distinct difference of biomedical ethics and ethics was not of great importance and such expediency was determined only in connection with the expansion of the object of the ethic analysis from human to all living organisms and ecology on the whole.

Biomedical ethics as a subject originated from several stages of the medical ethics development6. "Biomedical ethics" in its turn became the base for the formation of global bioethics, which is now transforming into new quality that we suggest to define terminologically as "nooethics". Expediecy of introduction of the new term is determined by historical succession between medical ethics, biomedical ethics and global bioethics.

Biomedical ethics originated from three stages of medical ethics development:

I the stage of the formation of ethics and principles of medical ethics;

II the stage of the formation of corporative medical ethics;

III the deontologic stage.

The first stage of the formation of ethics and principles of medical ethics originated from the primitive ethics and formation of medicine in the family community, which began to produce foodstuffs. The first stage contains the works of the great classical Greek philosophers - Socrates, Platone, Aristotel as well as the way of medical ethics from the acient shamanism, the precepts of the Egyptian healer Imhotep, the code of the ruler Hammurapi up to the ethic works of Hippocrates's school ${ }^{11}$.

The second stage is the formation of corporative medical ethics. It is associated with appearance and distribution of monotheistic religions such as: Buddhism, Iudaism, Christianity, Islam. It is also associated with the works of Paracelcium, A. Vesalius, Harvey, Malchipij, Persifal and in future it was associated with the creation of medical faculties and medical corporations. Independence and spread- ing of the physician profession and growth of its prestige resulted in opening of medical faculties. A physician becomes also a scientist and a doctor in the renewed meaning of this word. Graduates from the medical faculties give "faculty promise", the content of which was approximately the same as of the text of "Hippocrate's Oath". The creation of medical corporations resulted in actualization of medical ethics problems, although corporated ethics was primarily aimed at the defence of the interests of medical community but not of a sick person.

The third stage (deontologic) is conditionally dated by 1834 - the time of publication of the book of the English philosopher and lawyer J. Bentham (1748-1832) "Deontology or the science on moral". The significant role in the development of classic theories of deontology belongs to such outstanding philosophers as D. Mil, E. Cant, V. Ross. During the process of devision and extending deontologic theories from the positions of various philosophic systems the principles and postulates of worthy doing the duty, ethic requirements and standards were substantiated.

It is interesting to note that deontology as a part of the ethic theory covered essentially the content of the most various occupations and specialties. However, with the course of time it started to deal mostly with the ethic problems of medicine ${ }^{8,9,10}$. As a result, medical ethics has been more frequently termed as medical deontology by the end of the $19^{\text {th }}$ century. It is in this connection that the period of the intensive development of deontology beginning from the classic works by J. Bentham was called the deontologic stage of development of medical ethies. Deontology as a doctrine on the moral duty became a science of practical use of the principles and standards of medical ethics in different branches of medicine. It also became a school of medical humanism and moral professionalism. Deontology fights against commerceolization of medicine, for the observation of patients' interests and professional physicians' rights.

The physicians proved to be among the first who raised their voices against production, distribution and application of bacteriological, chemical and nuclear weapons. One of them is academician Ye. I. Chazov Nobel prize winner, the Honorary Doctor of Odessa State Medical University.

The significant role in the analysis of the results of the deontologic stage of medical ethics development and the formation of philosophic- and-analytical base of the next stage - bioethic, belongs to the outstanding personality, one of the greatest persons of the $20^{\text {th }}$ century A. Schweitzer (1875 -1965). There is no division into more valuable and less valuable life into the higher and lower in his ethics of "reverence for life". Considering each form of life to be sacred and inviolable, A. Schweitzer criticized anthropocentricity for narrow limits of interhuman relations and widened the biblical commandment "don't kill". He had all rights to say: "My argument is my life'*. A. Schweitzer was the man whose range of interests was really great. He became famous not only as a talanted physician but also as a thinker, a humanist, a philosopher, a theolo- 
gian, a priest, a musician, a music expert, a writer, a journalist, a social worker and a philanthropist. He was honoured with the name of Nobel prize winner. His contribution to the development of medical ethics is great. A. Schweitzer created new thinking, which includes conception of defence of the environment. New thinking meant recognition of responsibility of inhabitants of our planet for preservation and prolongation life on the Earth. Survival will be possible if the change of mentality leaves behind the rate of technical progress, if the gap between the poor and the rich decreases, if expenses for arms are reduced, but economic progress is not accompanied by destruction and degradation of the environment. A. Schweitzer may truly be considered as the founder of the ecological science. A. Schweitzer realized the problem, which had arisen in front of the mankind in the middle of the $20^{\text {th }}$ century: the expotential growth of knowledge is not accompanied by the increase of wisdom necessary for the control of this knowledge.

A. Schweitzer's ethics, which is characterized by universalism and globality was aimed at overcoming this gap and finding the way out of spiritual crisis of the $20^{\text {th }}$ century. A. Schweitzer saw that the cause of contemporary moral crisis was in opposition of ethics of personality and society. According to A. Schweitzer, all variety of ethic systems and ideologies may be brought together to two main types: ethics of self-denial and ethics of perfection.

Ethics of self-denial is of social-utilizing character and means that each individual should sacrifice himself for the sake of others and society on the whole. Another type of ethics is ethics of self-perfection of a moral personality. A moral personality is in constant dispute with the community ethics due to differences in the assessment of humanity and he cannot obey it absolutely. A. Schweitzer considers that ethics of the moral personality should be in the first place and community ethics can be moral only through recognition of individual ethic values. A. Schweitzer thought a statement that ethics of moral personality and community ethics couldn't be united in the uniform system of ethic values to be a great error.

The International Medical Academy named after A. Schweitzer carries out a lot of work on popularization of Schweitzer's creative inheritance.

IV stage of development of medical ethics formation of biomedical ethics has been started since 1970- the time of publication of basic works of and biochemistry W. Potter. Development of biomedical ethics was a direct consequence of practical introduction of achievements of scientific and technological revolution under the conditions of deep ideological crisis and increasing load of global ecological problems.

Great progress of medical-biological sciences gave rise to numerous complex problems of moral character. It was carried so far that man tried to control his own evolution and claimed for not only supporting his life but also improving and changing his nature to his own interpretation. These situations cause grounded discussions of ethic basis and moral right of such actions. The subjects of intensive dis- cussion and analysis are ethic problems of clinical trials and experiments on animals, gene engineering, transplantation of organs and tissues, new reproductive technologies, euthanasia.

Biomedical ethics as a modern stage of medical ethics is directed at energetic search for ways of humanization of medicine and medico biological science by comparing possibilities of medicine and biology with human rights. The idea of "constructing a bridge" to connect such principally different phenomena as biology and ethics belongs to V.Potter. Since the beginning of their existence natural sciences have been oriented at objectiveness as ideal of spirituality, study of objective reality without subjective experience and moral and ethic assessment of man. The essence of the historically formed conflict between naturalism and humanism consisted in ignoring information and knowledge beyond investigation competence of descriptive and experimental science. According to V. Potter, bioethics is not only a bridge between different disciplines but also "a bridge to the future", which is needed "for connection of medical ethics and ethics of environment on the global scale to ensure man survival". It is global bioethics based on intuition and intellect (logics) confirmed by emperic knowledge of all branches of science, and especially biology "that can and must ensure" long-term survival of the mankind as a species in normal and stable civilization". Ethics, which was historically anthropocentric field of knowledge and studied the relationship of "man-toman", also began to consider the sphere of the live (A. Schweitzer) and then the notion of morality involved the nature on the whole (V. Potter).

Thus, it is expedient to differentiate biomedical ethics as a stage of development of medical ethics and bioethics as more extended field of knowledge that makes its task to protect physical, mental and spiritual integrity of man, its genome, protect animal and plant world and environment $^{2,3}$. It represents a complex of measures on systematic analysis and coodination of man's action in the field of medicine, biology and ecology from the point of view of generally accepted moral values and principles.

\section{GLOBAL ECOLOGICAL CRISIS}

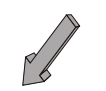

Philosophical and ideological aspects
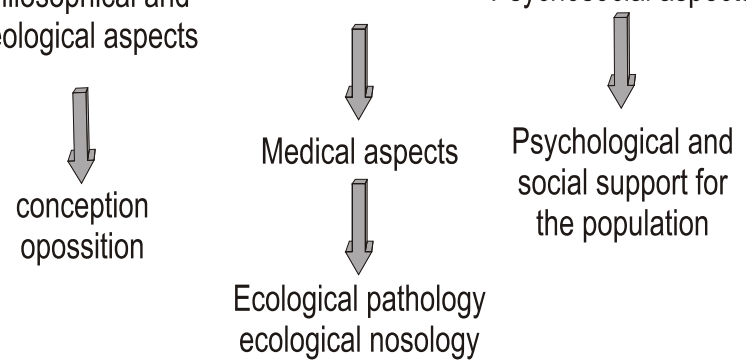

Fig. 1. 
In the $20^{\text {th }}$ century the mankind faced the disastrous consequences of global ecological crisis. This principally new phenomenon raised a question of physical survival, continuation of the human race and development of civilization. The critical phase of relationships and controversies between the society and nature is conditioned by titanic growth of consumption of natural resources, change of landscapes, creation of new anthropogenic medium and disturbance of dynamic balance in the biosphere at different levels of its organisation. It is evident that solution of the problem of global ecological crisis is associated with a solution of amalgamation of goals of economic basis with maintenance of ecological balance and resource stability (Fig. 1)

First of all, the global ecological crisis has philosophic and ideological aspects due to necessity of devising conception of interaction. Psycho-social aspects of the problem are of great importance, and they are reflected in necessity of psychological and social support of the population. Medical aspects of global ecological crisis are connected with prevention and therapy of ecological pathology and ecological nosology. The global ecological crisis raised a number of questions and their solution became an immediate task of the mankind in the $21^{\text {st }}$ century.

1. Are the prognoses of disastrous development of conflict between the mankind and environment real?

2. Is the mankind capable of overcoming the global ecologic crisis?

3. Is the ecological situation a consequence of the human lack of fore-sight, greed and stupidity or is it a result of natural evolution of the biosphere from the point of thermodynamic law of increasing entropy, increasing chaos and simplification of the system "mankind-nature". Answers to these questions determine strategy of the mankind survival in the $21^{\text {st }}$ centure. Bioethics, in the broad sense of this word, became the answer to negative consequences of introduction of the newest medical and biological technologies and manifestations of the global ecological crisis under the conditions of ideological insolvency of the society. From our point of view, it is appropriate to include the notion of "global bioethics" into terminological use (i.e. bioethics in the broad sense). Biomedical ethics and ecoethics should be considered as its constituents; they have arisen due to realized striving of the mankind to survival by preserving the biosphere based on amalgamation of modern achievements of science and practice with moral and spirituality as well as protection of natural control mechanisms of the biosphere.

Retrospective assessment of bioethic history gives evidence that it concentrated its attention on advocacy of human rights in the $70^{\mathrm{s}}$, it was aimed at the problem of life quality improvement in the $80^{\mathrm{s}}$ and it got a character of global bioethics in the $90^{\text {s. }}$. Unfortunately, despite realization of threat of global ecological disaster, energetic work of bioethic institutions, governments, parliaments, governmental and nongovernmental organisations, physicians, lawyers, teachers and ecologists, church and public at large, negative tendencies of the biosphere degradation failed to be overcome in the second part of the $20^{\text {th }}$ century with the mankind entered the $21^{\text {st }}$ century with a growing load of unsolved problems.

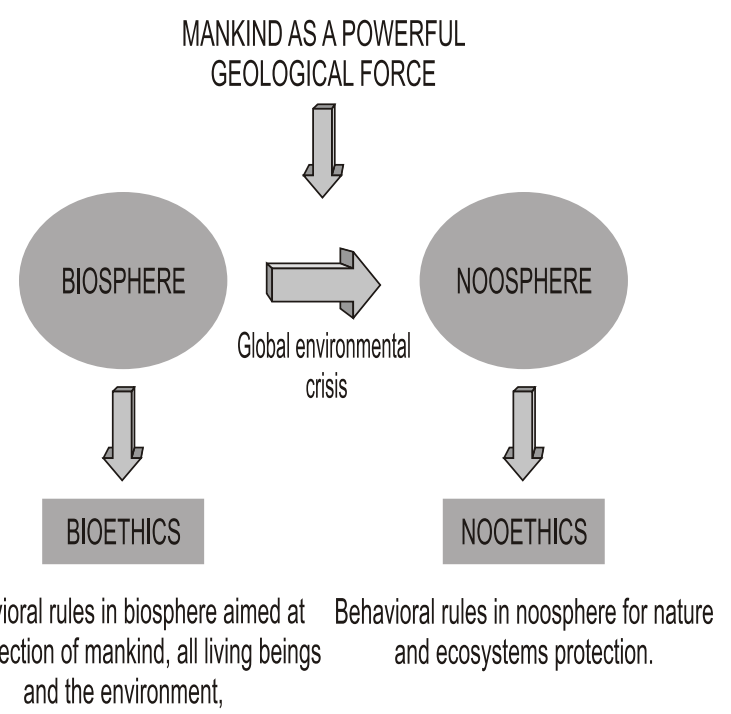

To our mind, medical ethics begins its next, the 5 th stage of historical development, which is stipulated by the level of unreversable changes of relationship balance between man and nature achieved by civilization. Philosophic and ideological principles of this stage are determined by the conception of the academician V. I. Vernadsky about the biosphere and its transformation resulted from the human activities as powerful geological force into the Noosphere (Fig. 2). The Biosphere has its specific control mechanisms that are to protect the Earth, the entire Biosphere and mankind. At present inhabitants of the Earth of the $21^{\text {st }}$ century realize that the mankind destroyed control mechanisms of the Biosphere. While redoing the nature and environment man changed the life conditions on the planet by his intellect, results of the intellectual work and created his Noosphere that in contrast to the Biosphere, did not have its own control mechanisms. Under such conditions the influence of the living beings is accomplished not only directly but also indirectly, i.e. via the transformed Biosphere. This influence may be realized but it is unrealized in most cases. Man made a very complicated technical equipment; and at present he tests new forms of dependency: dependence on computer, TV programmes, Internet. He created virtual reality that is able to effect human behaviour. At present elements of artificial intellect have been developed and investigations are in progress. Being aids computers become equal participants of communication and will be able to make decisions in the future. The living beings cross the life frontiers into the virtual reality. Culture is substituted for a system of rationalistic constructions. Spirituality is reduced to the intellect, and values are changed by specific aims. Principles of profit, liberalism and benefit are dominated. There is noted a tranfer of the mankind to development deadlock when reproduction is substituted for cloning, teaching- for coaching and work for automated mechanisms.

Undoubtedly, modern society is in Noospheric crisis, its destructive consequences are enormous and the outcome is unpredictable. The Noospheric crisis consists in increased chaos, simplification of the system "mankind -nature", and 
may be characterized as a direct consequence of the thermodynamic law of growing entropy. The Noosphere is mortal as all alive and a man with his olitical and social contsructions, economic technologies and psychologic characteristics is not only an instrument for completing the cycle "birth-development-aging-death" of the Noosphere. This conception of ethics means that limitation of negative features of a personality (shortsightedness, selfishness, greed, stupitity) and enhancement of spirituality and humanism becomes the most important way of overcoming the noospheric crisis.

Unfortunately, former bioethic principles, methods and theories won't be adequate and effective enough in new reality $^{1,2}$. Under the conditions of the realized Noosphere the increasing interaction of an individual or the entire mankind with the objects of animate and unanimate nature takes place both by direct and indirect way through the modified Biosphere.

If the human activity in the Noosphere does not begin to be regulated with new ethic principles, the consequences of modern noospherical crisis may have global and disastrous character. For the maintenance of all living, for all nature and ecosystem on the whole, this new ethics has to become Nooethics, i.e. to become the rules of behaviour in the Noosphere, which would promote the global interests of all Noosphere components such as: the Planet, mankind and Biosphere, transformed by $\mathrm{it}^{12,13}$. Nooethics is meant to become one of the numerous control mechanisms of the Noosphere, which have to provide its stable existence and development. The creation of Nooethics may be regarded as the strategy of ethics development and provision of the mankind survival at the modern stage of its existance ${ }^{14}$.

Nooethics as the highest stage of Bioethics development has to enter the ethics as a part of Philosophy, and become an integral and very important part of it. Nooethics will promote the further development of Medicine and medicobiological science that permits to name the modern stage of medical ethics nooethic one.

The ethic orientation of Vernadsky's doctrine consists in that he connects the appearance of the Noosphere with transformation of the mankind into the entity as powerful geological force. According to his understanding, the thought, intellect are regarded as the moral intellect, which is able to be embodied in science, as well as in technology. By his expression "The truth, beauty and good are indivisible in the Noosphere".

The global mankind responsibility for the life on the Planet (in the Noosphere, according to V. L. Vernadsky) probably makes up the deep destination of man, his life, according to the moral principles of good, mercy and compassion in the harmony with himself and the world surrounding him.

In our opinion, one more tendency of society and science development, which coexists with the global process is worth our attention. It is tendency to the universalization and integration. With reference to ethics of Biology, Medicine, Ecology, Biosphere and Noosphere problems, it means the necessity of the drawing together and confluence of the West and East philosofic and ideologic views in dif- ferent countries, cultures and strata of multinational society. Therefore, it is quite appropriate to mark that global Bioethics (and Nooethics) were formed on the basis of the cultural phenomena of Europe and North America. Development of the European humanism traditions, Anglo-American philosophic tradition of utilitarian and liberal individualism form its ideological core. The Global Ethics and Nooethics are undoubtely close to Christian attitude towards the self-appraisal and the highest value of any life manifestation. On the other hand, the Global Ethics and Bioethics are the transnational cultural phenomenon, the part of such cultural trend as postmodernism with its all characteristic features.

We think that it is possible in principle and morally necessary to strive for the creation of universal and integrated theory of the global Bioethics and Nooethics on the basis of drawing together the Western and Eastern philosophic and ethic systems; Ukraine may and must make its contribution to ethics development in this direction. The geographical position of Ukraine which is situated between the West and East, undoubtly, influences on the formation of our philosophic views on science on the whole and on medicine with Biology, in particular. Historically, we have absorbed the elements of technocratics of the West and spirituality of the East. No doubt that such a harmonious unity promotes humanisation of Medicine, understanding of man as the entity of biological, psychological and social components. The daily collaboration in the administrative, scientific and educational fields promotes the mutual penetration, enrichment and drawing together of the West and East. We had the possibility to see it in the progress of realization of the partners' programmes, agreements and grants with the medical institutions of the Netherlands, Poland, Greece, Italy, Germany, Switzerland, the USA, India, Viet Nam, Syria, Egypt, Iran and Malaysia.

In conclusion, it should be noted, that the teaching of Biochemical Ethics at higher medical educational institutions of Ukraine has become the insistent necessity and for practical realization of this task, we together with our collegues from Kharkov, Vinitsa and Lvov medical universities have devised a programme of the elective course in "Bioethics" for the students teaching at higher medical institutions of the III - IV stages of accreditation in accordance with the curriculum of specialist training.

Formation and development of Nooethics can contribute to the evolution of biological science and modify the human activity, taking into account the priorities of the Noosphere, Biosphere and in the long run, the specific man. Therefore "Nooethics" as the highest stage of Bioethics development enters the mankind ethics and becomes as an integral and very important part of it.

\section{REFERENCES}

1. Aristondo J. A. Christian perspective on the use of animals for medical research and transplantation Ethics \& Medicine; Vol. 11, N3, 1995: 56-67. 
2. Baume P., O'Malley E. Euthanasia: attitudes and practices of medical practitioners - The Med. J. of Australia 1994: 161-142.

3. Bennet L E., Edwards E. B., Hosenpud J. D. Transplantation with older donor hearts for presumed stable recipient: an analysis of the Joint International Society for Heart and Lung Transplantation - United Network for Organ Sharing Thoracic Registry - J. Heart Lung Transplant. N 17, 1998: 901 -905.

4. Bioethics for scientists /Ed.by J.Bryant, L.Baggott la Velle, J.Searle.- John Willey \& Sons, LTD, 2002:360.

5. Bioethics. An Anthology - Ed. By H. Kuhze, P. Singer. Oxford: Blackwell Publ. Ltd, 1999: 600.

6. Bioethics: an introduction to the history, methods and practice - Ed.by N.S. Jecker, A.R. Jonsen, R. A. Pearlman. - London U K: Jones and Bartlett Publishers International 1997: 416.

7. Biomedica /ethics/ Ed. by T.A. Mappes, D. Degrazia.5th ed. N.Y. USA: Mc Graw Hill, 2001: 707

8. Brock L, Eidl M. D. The least a parent can do: prenatal genetic testing and the welcome to our children - Ethics \& Medicine, Vol. 13, №3, 1997: 59-66.
9. Dyson A. The Ethics of IVF (London: Monbray) - $J$. of the American Medical Assotiation N 66, 1995: 4-9.

10. Harris J. Is there a coherent social conception of disability? - J. of Medical Ethics Vol. 26, 2000: 95-100.

11. Iglesias T. Hyppocratic medicine and the teaching of medical ethics // Ethics \& Medicine Vol. 12, N 1, 1996: 4-9.

12. V. Zaporozhan. Nooethics and global bioethics. 2nd International Congress on THE "EUROPEAN CITIZEN'S QUALITY OF LIFE E.C. Qua. L", 2005. P.84-85.

13. V. Zaporozhan. Nooethics: as modern stage of development of bioethics. Leadership medica.-№ $\mathbf{1}$, 2005. - P. 17-21.

14. В. Запорожан. Нооетика - філософські та світоглядні основи глобальної біоетики. Лікарський вісник, рік 5, ч.1, (155), літо 2006, с. 56-62. 